Markewitz, K., G. Lefebvre, Cabral, A.R. and Panarotto, C.T.\# (2004). Anaerobic biodegra-dation of an organic by-product leachate by interaction with different mine tailings. J. Haz. Mat., 110(1-3): 93-104.

\title{
Anaerobic biodegradation of an organic by-products leachate by interaction with different mine tailings
}

\author{
K. Markewitz ${ }^{\mathrm{a}}$, G. Lefebvre ${ }^{\mathrm{a}}$, A.R. Cabral ${ }^{\mathrm{a},{ }^{,},}$, C.T. Panarotto ${ }^{\mathrm{b}}$ \\ ${ }^{a}$ Université de Sherbrooke, Sherbrooke, Canada \\ ${ }^{b}$ Universidade de Caxias do Sul, Caxias do Sul, Brazil
}

ABSTRACT: Deinking by-products from paper recycling has been used as cover material on acid-producing tailings. Due to remaining cellulose, anaerobic degradation leads to the production of an organic-rich leachate, which may percolate through the tailings. This study aims at describing the influence of the tailings' characteristics on the attenuation of organic matter in leachate and at discussing the degradation mechanisms. To this end, leachate was mixed with different types of tailings, including three unoxidized tailings with varying acid generation potentials and one tailing in three states of oxidation. Regularly, selected biochemical parameters were analyzed to access the evolution of organic components. The results show that when deinking by-products leachate was placed in contact with tailings, phase and acid-base balance reactions took place in the beginning. Subsequently, oxidationreduction reactions dominated the chemistry of the system. The type, the constituents and the state of oxidation of the mine tailings condition the mechanisms of biodegradation of organic components. Methanogenesis was predominant in the control sample (pure organic leachate) but was absent in all leachate-tailings mixes. No biodegradation was observed in

\footnotetext{
${ }^{*}$ Corresponding author: Tel: +1-819-821-7906; Fax: +1-819-821-8000-7974

E-mail : alexandre.cabral@usherbrooke.ca
} 
the liquid phase for oxidized tailings and the organic concentration remained constant for unoxidized tailings, independently of the acid-generation potential. The biodegradation efficiency was optimal when the leachate was in contact with a mixture of oxidized and unoxidized tailings due to sulfate-reduction.

Keywords: mine tailings, deinking by-products, organic leachate, biodegradation, natural attenuation

\section{INTRODUCTION: DEINKING BY-PRODUCTS COVERS FOR MINE TAILINGS}

In presence of water and oxygen, sulfide-rich minerals, found in mine tailings, produce sulfuric acid following a series of reactions mediated by sulfur- and iron-oxidizing microorganisms, such as Thiobacillus ferrooxidans [1], a species that thrives in acidic environments. The resulting low $\mathrm{pH}$ causes the dissolution of heavy metals and eventually the contamination of surrounding bodies of water. This is one of the most important problems of the mining industry and is referred to as acid mine drainage (AMD).

Covering the tailings presents several advantages: 1) It allows the stabilization of the mine wastes by preventing wind and water erosion; 2) It improves the esthetic view of the site and 3) It prevents or inhibits the dissolution and leaching of contaminants [2]. Since AMD requires oxygen as reagent, one solution to prevent it is the placement of an oxygen barrier as a cover system. Various organic materials have been tested as alternative cover materials: wood chips [3], compost from municipal solid wastes [4] or deinking by- 
products, a material resulting from the paper recycling process ([5-7]). Barriers with high organic material contents, such as deinking by-products, can constitute both a physical barrier to $\mathrm{O}_{2}$ flux [7] and an oxygen-consuming barrier [8]. Indeed, due to the high cellulose content of deinking by-products [8], aerobic degradation takes place, consuming any $\mathrm{O}_{2}$ that migrates through it. Due to the high organic content of deinking by-products (DBP), aerobic and anaerobic microorganism populations are very active; the first near the surface, the second deeper into the barrier. Uncompleted degradation in these two environments leads to the formation of an organic leachate that eventually percolates to the underlying mine tailings [9]. When this organic leachate comes in contact with the tailings, several physical, chemical and biological processes are likely to take place, leading to significant changes in the quality of the percolating water.

\section{BACKGROUND: LEACHATE-TAILINGS INTERACTION}

Although the fate of organic leachates that percolate into mine tailings under anaerobic conditions is not well documented in technical literature, the anaerobic reactions occurring when AMD-contaminated water goes through organic filters have been investigated $\mathbb{1 1 0 -}$ 14]). Based on the results of these studies, the following phenomena might occur when the deinking by-products leachate percolates through mine tailings: organic inhibition of acid mine drainage, buffering and biodegradation. The increase of $\mathrm{pH}$ and/or the removal of heavy metals were observed in several studies that evaluated the efficiency of covers $([3,4,15])$. These studies associated changes in $\mathrm{pH}$ and metal concentration inside the 
tailings to the covering and to the interactions with the leachate produced. These interactions seem to contribute to the reduction of the existing acidity.

When an organic leachate is in contact with mine tailings, some chemical and biological interactions are likely to take place. The first step is a chemical balance between the components of tailings and those of deinking leachate. This is likely to favor the buffering of the tailings environment given the alkalinity of the components of deinking byproducts leachate [8]. Subsequently, because of changes in the chemical environment, the competition between microorganisms is enhanced. Those whose activity is measured before the contact, may or not be out-competed by other species in a new environment, or else inhibited.

\subsection{Chemical Buffering}

Buffering mine wastes by deinking by-products leachate is likely to occur first as a result of acid-base reactions. Calcite and organic acids, two important components of deinking by-products [8], may have a buffering impact on AMD. Carbonate and bicarbonate from the calcite dissociation in the presence of protons (i.e. $\mathrm{H}^{+}$resulting from sulfuric acid) increase the $\mathrm{pH}$ of the system and carbon dioxide is produced. Organic acids and carbonates also interact together and buffer the acidic pore water according to chemical reactions 1 and $2[9]$.

$2 \mathrm{CH}_{3} \mathrm{COOH}+\mathrm{CaCO}_{3} \leftrightarrows \mathrm{Ca}^{2+}+\mathrm{CO}_{3}{ }^{2-}+2 \mathrm{CH}_{3} \mathrm{COO}^{-}+2 \mathrm{H}^{+}$

$\mathrm{H}_{2} \mathrm{CO}_{3}+\mathrm{Ca}^{2+}+2 \mathrm{CH}_{3} \mathrm{COO}^{-} \leftrightarrows \mathrm{CO}_{2}+\mathrm{H}_{2} \mathrm{O}+\mathrm{Ca}^{2+}+2 \mathrm{CH}_{3} \mathrm{COO}^{-}$ 


\subsection{Organic leachate impact on acid mine drainage mediators and products}

AMD is due to a series of reactions mediated by autotrophic acidophilic microorganisms. The reagents are sulfide minerals, oxygen, and the products are protons, soluble metals and sulfate. When organic components are in contact with pore water affected by AMD, chemical and biological interactions may take place in the system. They may decrease the impact of AMD on the environment by acting either on mediators and/or on reagents and/or on products.

In mine tailings, numerous autotrophic and heterotrophic microorganisms coexist [2]. The most studied microorganism is Thiobacillus ferrooxidans, which catalyzes AMD enhancing reactions. The percolation of organic leachate through tailings transforms the biochemical balance and may favor the development of other microorganisms, especially heterotrophic ones. Moreover, Thiobacillus genus is sensitive to numerous components, particularly to organic acids. By adding different orga nic materials to mine spoils, Pichtel \& Dicks (1991) [13] observed a decrease in total soluble iron and in sulfur derived components. At the same time, the $\mathrm{pH}$ increased by the influence of organic components on the activity of acidophilic microorganisms.

Organic components can also react with the products of AMD reactions such as heavy metals to form complexes, which help to prevent their transport. This occurs by means of time-, metal and $\mathrm{pH}-$ dependent reactions [16]. Moreover, organic components, such as organic acids, react as electron donor in several reactions mediated by microorganisms. The obtained products cause an impact on the water quality of acid generating mine tailings. 


\subsection{Biodegradation}

Panarotto et al. [9], who have monitored data from several mine and landfill sites where deinking by-products were used as cover materials, have shown that the environment under the layer is essentially anaerobic. As a consequence, microorganisms that oxidize the deinking by-products leachate in the mine tailings environment must be anaerobic.

Teixeira [8] noticed that methane-producing and fermentative microorganisms are present in the degraded deinking by-products. These microorganisms are thus likely to migrate into the tailings. According to Ledin and Pedersen [2], numerous microorganisms are present in the mine tailings such as autotrophic Thiobacillus genus and numerous heterotrophic gena (Acidiphilium, Bacillus, Desulfovibrio, Pseudomonas, Staphylococcus, Micrococcus, Arthrobacter or Streptomyces gena) .

In relation with the electron receptors present in the mine tailings, expected anaerobic biodegradation of organic components from the deinking by-products leachate may result from methanogenesis, sulfate reduction or iron-reduction (simplified chemical reactions 3 to $5)$.

$\mathrm{CH}_{2} \mathrm{O} \rightarrow \mathrm{CO}_{2}+\mathrm{CH}_{4}$

$2 \mathrm{CH}_{2} \mathrm{O}+\mathrm{SO}_{4}{ }^{2-}+\mathrm{H}^{+} \rightarrow 2 \mathrm{CO}_{2}+\mathrm{HS}^{-}+2 \mathrm{H}_{2} \mathrm{O}$

$\mathrm{CH}_{2} \mathrm{O}+4 \mathrm{Fe}(\mathrm{OH})_{3}+8 \mathrm{H}^{+} \rightarrow \mathrm{CO}_{2}+4 \mathrm{Fe}^{2+}+11 \mathrm{H}_{2} \mathrm{O}$

According to these reactions, the alkalinity of the medium is increased by producing carbonates in methanogenesis (reaction 3), sulfate-reduction (reaction 4) and iron-reduction 
(reaction 5) and by the consumption of protons during sulfate and iron reduction (reactions 4 and 5). These processes would result in the buffering of the acidic pore water in mine tailings. In addition to the consumption of organic components, the anaerobic oxidation of organic matter thus has an influence on the alkalinity and mobility of the AMD products. Indeed, the products of these biodegradation processes, such as carbon dioxide (from reactions 3 to 5) and hydrogen sulfide (from reaction 4), have the capacity to form complexes with soluble metals and precipitate in the form of metal carbonate and metal sulfide [17], thereby, limiting the negative impact of AMD on the environment. For these reasons, understanding biodegradation of organic-rich leachate by mine tailings is a relevant environmental issue.

The aim of the present study is to evaluate the attenuation of deinking by-products leachate-in contact with different mine tailings. Laboratory tests are thus performed to assess the influence of mine tailing characteristics, such as acid generation potential and the oxidation state of mine tailings, on the attenuation of organic components. The results of laboratory tests are presented and discussed and the various phenomena that take place are explained. 


\section{MATERIALS AND METHODS}

\subsection{Mine tailings and leachate}

Four different types of mine tailings were used during the study: three unoxidized mine tailings (Grevet, Doyon, Laronde) and one oxidized mine tailing (Doyon ox). The physicochemical characteristics of the oxidized and unoxidized tailings are shown in Table 1. Their characteristics differ significantly, in particular the acid generation potential (AGP), which is the sum of the acid potential (AP) and the neutralization potential (NP). The AP is the capacity of a tailing to produce acidic components, represented as a negative number. It is calculated from the percentage of sulfur in the materials. The neutralization potential (NP) is the acid consuming capacity of mine tailings, measured by titration. Among the three mine tailings studied, Laronde tailings have the highest capacity to produce acid $(-956 \mathrm{~kg}$

$\left.\mathrm{CaCO}_{3} \cdot \mathrm{t}^{-1}\right)$ and the weakest capacity to consume them $\left(20 \mathrm{~kg} \mathrm{CaCO} \cdot \mathrm{t}^{-1}\right)$. This results in a high potential of AMD $\left(-936 \mathrm{~kg} \mathrm{CaCO} \cdot \mathrm{t}^{-1}\right)$. Grevet tailings have the most important neutralization potential of the three unoxidized tailings $\left(60 \mathrm{~kg} \mathrm{CaCO}_{3} \cdot \mathrm{t}^{-1}\right)$ but their acid potential is also high, resulting in a still high AGP ( $\left.-618 \mathrm{~kg} \mathrm{CaCO}_{3} \cdot \mathrm{t}^{-1}\right)$. Doyon tailings have the lowest capacity to generate AMD $\left(-82 \mathrm{~kg} \mathrm{CaCO} \cdot \mathrm{t}^{-1}\right)$ due to a low AP $(-123 \mathrm{~kg}$ $\left.\mathrm{CaCO}_{3} \cdot \mathrm{t}^{-1}\right)$ and relative equilibrium between AP and NP.

The pHs are also quite different depending on the unoxidized tailings. The lowest value (5.15) was obtained for Laronde tailings, whereas the highest value (8.93) was obtained in Doyon tailings. A pH of 5.39 was measured in Grevet tailings. the low $\mathrm{pH}$ of the oxidized Doyon tailings (3.18) is associated with a concentration of soluble iron ten times higher than what was measured in the unoxidized Doyon tailings. 
The mineralogy of the tailings showed that quartz was identified in all tailings and sulfide minerals were found only in unoxidized tailings. In unoxidized tailings, pyrite $\left(\mathrm{FeS}_{2}\right)$ and sphalerite $(\mathrm{ZnS})$ are the main sulfide minerals. Chalcopyrite $\left(\mathrm{CuFeS}_{2}\right)$ was also found in unoxidized Doyon tailings and chalcocite $(\mathrm{Cu} S)$ in the Grevet tailings.

The deinking by-products leachate used in the study was taken from a well installed inside the deinking by-products cover of the Eustis mine site, located near Sherbrooke, Quebec, Canada [18]. The main characteristics of this leachate are presented in Table 2. They are a $\mathrm{pH}$ close to neutrality and a high alkalinity associated with a high concentration of calcite and organic matter. Moreover, the organic parameters (COD and TOC) are representative of an average organic charge for a deinking by-products leachate [8]. ,

\subsection{Sample preparation}

A total of 180 serum bottles were filled with different mixes of leachate and tailings. Five series of mixes of leachate and tailings, plus a control (leachate without any contact with mine tailings) were prepared. The five series correspond to mixes of leachate with: 1) three different kinds of uno xidized tailings with varying acid ge neration potential (Grevet, Doyon, Laronde); and 2) Doyon tailings in three different states of oxidation (oxidized, unoxidized and a mix of unoxidized and oxidized tailings).

A total of $15 \mathrm{~g}$ of each type of tailings ( $10 \mathrm{~g}$ of unoxidized and $5 \mathrm{~g}$ of oxidized, in the case of the mix) were placed in serum bottles equipped with a butylic rubber stopper and Weathon seals to avoid gas diffusion during the ten-month study. Once the bottles were sealed, they were purged with sterile nitrogen gas in order to remove oxygen from the 
bottle, and to create an anaerobic environment. In sterile conditions, $7.5 \mathrm{ml}$ of leachate were injected in the bottle using a syringe. Purging with nitrogen gas was repeated to ensure anaerobic conditions. The serum bottles were stored in darkness, at $37^{\circ} \mathrm{C}$ and randomly placed.

\subsection{Analyses}

At every sampling occasion, three serum bottles from each series were randomly chosen and weighed. The gas produced was collected with a syringe and the concentrations of $\mathrm{CO}_{2}, \mathrm{CH}_{4}$ and $\mathrm{O}_{2}$ were measured using a Gas Analyzer LFG 20 (ADCcie).

Each bottle was then opened and all the content was poured into centrifuge bottles. A volume of $7.5 \mathrm{ml}$ of deionized water was added. After ten minutes of stabilization, the redox potential was obtained using a platinum redox electrode (VWR brand Electrodes) combined with a silver/silverchloride reference electrode. The $\mathrm{pH}$ was then measured with a Hach One-pH-meter (model 48600) using a glass electrode coupled with a silver/silver chloride reference electrode (ASTM D4972). The calibration used $\mathrm{pH} 4$ and 7 solutions.

Another $15 \mathrm{ml}$ of deionized water was added and the bottles were centrifuged at 10000 rpm for 30 minutes at $20^{\circ} \mathrm{C}$ to separate the liquid from the solid phase. The two phases were stored in polyethylene bottles at $4^{\circ} \mathrm{C}$, and stored according to the storage method of each subsequent analysis to be performed.

The solid materials were weighed, dried at $105^{\circ} \mathrm{C}$ for 12 hours and weighed again in order to calculate the amount of retained leachate and adjust the volume data. The parameter chosen as the biodegradation indicator in the solid phase was the total organic carbon (TOC). The TOC was obtained by potassium dichromate digestion and colorimetric analysis 
using a Hach DR/2000 direct reading spectrophotometer (Hach Method 8097). The TOC in solid phase is denoted as $\mathrm{TOC}_{\mathrm{s}}$.

The parameters analyzed for the liquid phase were the Total Organic Carbon (TOC), total iron and total calcium. For TOC determination, the liquid was acidified by phosphoric acid and maintained in a nitrogen flow for 5 minutes in order to extract inorganic carbon. A sample of $40 \mu \mathrm{l}$ was injected in a TOC analyzer DC-80 (Dohrman, Envirotech Co) using persulfate and ultraviolet in order to convert TOC into carbon dioxide, which was then measured following the Standard Method 5310C. The calibration used a $1000 \mathrm{mg} / \mathrm{l}$ standard solution. The TOC in the liquid phase, denoted on $\mathrm{TOC}_{1}$, allows to access biodegradation within the tailings because this component may eventually be leached through the tailings, thus contaminating the environment. In addition, biodegradation of organic components takes place in the liquid phase, as is discussed later in the paper.

Calculations were then performed to determine the precipitated inorganic carbon from the variations of soluble calcium. The inorganic carbon in the liquid phase was calculated based on the amounts of solid calcite, gaseous $\mathrm{CO}_{2}$ and gaseous $\mathrm{CH}_{4}$. Statistical analysis (covariance analysis) on the sum of all the measured and calculated carbon was performed in order to verify the hypothesis of stability of total carbon concentration throughout the ten months of the study. 


\section{RESULTS AND DISCUSSIONS}

\subsection{TOC evolution in the liquid phase - General}

The evolution of the organic characteristics focused on the $\mathrm{TOC}_{1}$ concentration. Indeed, the biodegradation takes place in the liquid phase and its characteristics correspond to the ones, which will be likely to contaminate the environment. Figure 1 presents the evolution of $\mathrm{TOC}_{1}$ concentrations, measured during the nearly 250 days of this study. Each point represents the average of 3 results. The upper half of the standard deviation is represented. The pattern of $\mathrm{TOC}_{1}$ evolution depends on the type of tailings or mix of tailings. In the control (leachate without any contact with mine tailings), two evolution phases were observed: the TOC first increases from $1295 \mathrm{mg} / \mathrm{l}$ to $3662 \mathrm{mg} / \mathrm{l}$ for 75 days, and decreases after this period, to a value of $587 \mathrm{mg} / \mathrm{l}$. In unoxidized mine tailings (Grevet, Doyon and Laronde), with the exception of the first 14 days, the evolution of $\mathrm{TOC}_{1}$ is stable at 2680 $\mathrm{mg} / \mathrm{l}$ for Grevet, $2500 \mathrm{mg} / \mathrm{l}$ for Doyon and $2600 \mathrm{mg} / \mathrm{l}$ for Laronde. The sharp increase during the first 14 days could be associated with balance reactions involving organic carbon in the liquid phase and organic carbon in the solid phase. $\mathrm{TOC}_{1}$ concentrations in the oxidized tailings (Doyon ox) are quite stable at $2300 \mathrm{mg} / \mathrm{l}$ during the study. For the deinking leachate in contact with a mix of oxidized and unoxidized mine tailings (Doyon mix), the $\mathrm{TOC}_{1}$ concentration first increases sharply. This phenomenon was previously observed with the unoxidized Grevet and Doyon mine tailings. After this peak, the TOC concentration decreases to $170 \mathrm{mg} / \mathrm{l}$ after 100 days and stabilizes at this value.

Table 4 presents the variations of $\mathrm{TOC}_{1}$ and $\mathrm{TOC}_{\mathrm{s}}$ concentrations and the production of $\mathrm{CO}_{2}$ and $\mathrm{CH}_{4}$ for the first 14 days. In the Grevet, Doyon and Doyon mix, the increase of 
$\mathrm{TOC}_{1}$ concentration is lower than the decrease of $\mathrm{TOC}_{\mathrm{s}}$ concentration (Table 4). The hypothesis that the peak is the result of solubilization of organic carbon from the solid phase then seems to be plausible.

Further analysis in order to explain the results presented in Figure 1 will be provided in the following sections.

\subsection{Evolution of the control (leachate only)}

In the control (leachate only), the increase in $\mathrm{TOC}_{1}$ in the first 75 days indicated in Figure 1 can only be explained by the transformation of inorganic carbon into organic carbon. This type of transformation is mediated by autotrophic microorganisms. From the study of the microbiological and physico-chemical characteristic of the deinking byproducts leachate, there are reasons to infer that these autotrophics are methane-producing microorganisms. First, methane is produced throughout the study, as shown in Figure 2. Second, Teixeira [8] identified that methanogenic microorganisms Sarcinia in consortium with Bacillus are the main microorganisms present in deinking by-products pore water. Finally, methanogenic microorganisms can be autotrophic or heterotrophic.

That consortium may interact as follow: Bacillus, a diversified chemoheterotrophic gena, may ferment organic matter to produce $\mathrm{H}_{2}$ according to reaction 6 .

$\mathrm{C}_{2} \mathrm{H}_{5} \mathrm{COO}^{-}+3 \mathrm{H}_{2} \mathrm{O} \rightarrow \mathrm{CH}_{3} \mathrm{COO}^{-}+\mathrm{HCO}_{3}^{-}+\mathrm{H}^{+}+3 \mathrm{H}_{2}$ 
Methanogenic microorganisms couple the oxidation of $\mathrm{H}_{2}$ with the reduction of carbonate (reaction 7) and multiply, thereby increasing the biomass of the system, thus the TOC.

$$
\mathrm{H}_{2}+0,25 \mathrm{HCO}_{3}{ }^{-}+0,25 \mathrm{H}^{+} \rightarrow 0,25 \mathrm{CH}_{4}+0,75 \mathrm{H}_{2} \mathrm{O} \quad ? \mathrm{G}^{\mathrm{o}}=-33,9 \mathrm{~kJ} / \mathrm{mol}
$$

The rapid increase in carbon dioxide and methane production that takes place after 75 days (Figure 2) coincides with the period during which a decrease of $\mathrm{TOC}_{1}$ concentration was observed (Figure 1). This seems to indicate that beyond this point, methane-producing heterotrophic, which oxides organic matter (reaction 8), becomes predominant.

$\mathrm{CH}_{3} \mathrm{COO}^{-}+\mathrm{H}_{2} \mathrm{O} \rightarrow \mathrm{CH}_{4}+\mathrm{HCO}_{3}^{-} \quad ? \mathrm{G}^{\mathrm{o}}=-31 \mathrm{~kJ} / \mathrm{mol}$

\subsection{Evolution of leachate in contact with tailings at different states of oxidation}

Just after being deposited, mine tailings are unoxidized. In contact with water and oxygen, the sulfide minerals are oxidized, resulting in the generation of acid mine drainage and a quite different physico-chemical environment. In the serum bottles, deinking byproducts leachate was placed in contact with these two kinds of tailings. In order to evaluate the impact of eventual mixing, a series of tests were performed using a mixture of oxidized and unoxidized Doyon tailings.

Figure 1 shows that the variations of TOC concentration in the liquid phase follow very different patterns depending on the state of oxidation of the Doyon tailings. 


\subsubsection{Evolution of leachate in contact with unoxidized Doyon tailings}

When deinking leachate is placed in contact with unoxidized Doyon mine tailings, at first, a phase balance occurs due to the contact between two different materials (organic leachate and mine tailings). It is characterized by an increase of $\mathrm{TOC}_{1}$ concentration accompanied by a decrease of $\mathrm{TOC}_{\mathrm{s}}$ concentration (Table 4), and by an increase in iron concentration in the liquid phase (Figure 4c). The acid-base reactions are also rapidly balanced leading to an increase in $\mathrm{pH}$ from 6.5 to 9 in 14 days (Figure 4a). This increase in $\mathrm{pH}$ is associated with a light $\mathrm{CO}_{2}$ production (Figure 3) due to calcite dissociation as the results of Figure 4d conclude.

After this phase, oxidation-reduction reactions became predominant. The ones studied in this document involve the consumption of organic matter. They are evidenced by the sharp decrease in $\mathrm{TOC}_{1}$ concentrations from 4800 to $2800 \mathrm{mg} / 1$ for unoxidized Doyon tailings (Figure 1). Moreover, as indicated in Table 6, the $\mathrm{TOC}_{\mathrm{s}}$ concentration in unoxidized Doyon tailings decreased throughout the study by $76.6 \%$ (or from 104 to $24 \mathrm{mg}$ ).

Figure 5 presents the evolution of the carbon in the different phases. Whereas the percentage of carbon represented by the $\mathrm{TOC}_{1}$ concentration is steady after the $50^{\text {th }}$ day, the percentage of organic carbon in the solid phase decreased and was compensated by an increase in inorganic carbon in the solid phase. However, it is impossible that organic carbon in the solid phase be directly converted into inorganic carbon in the solid phase. This conversion must take place in the liquid phase. Contrary to the phenomena observed in the control, the conversion is not due to methane-producing microorganisms. Indeed, throughout the study, no methane was measured in any serum bottle of unoxidized tailings. 
This means that the active methanogenic microorganisms in deinking by-products leachate are unable to develop in the physico-chemical environment prevailing in unoxidized mine tailings.

The $\mathrm{pH}$, the redox potential (6 and $-100 \mathrm{mV}$ respectively (Figure $4 \mathrm{a}$ and $\mathrm{b}$ ) and the quick precipitation of iron (Figure 4c) seem to indicate that the degradation of $\mathrm{TOC}_{\mathrm{s}}$ may associate with the activity of iron-reducing micro-organisms. This issue is discussed later in the paper.

\subsubsection{Evolution of the leachate in contact with oxidized tailings of Doyon}

In the serum bottles filled with oxidized tailings, the TOC concentration in the liquid phase initially increased from $1500 \mathrm{mg} / 1$ to $2300 \mathrm{mg} / \mathrm{l}$. It then stabilized for 160 days to slightly increase again to $2600 \mathrm{mg} / \mathrm{l}$ (Figure 1). As shown in Figure 6, this initial increase in organic carbon content coincides with a decrease in inorganic carbon. Although the particular mechanisms responsible for this exchange were not clearly identified because of the brevity of the phenomena, they are likely not associated with the activity of microorganisms. Moreover, the redox potential of $+150 \mathrm{mV}$ obtained after stabilization (Figure $4 \mathrm{~b}$ ) and the $\mathrm{pH}$ in the vicinity of 4 (Figure $4 \mathrm{a}$ ) do not represent a favorable environment for the development of numerous anaerobic microorganisms.

As a means of verifying the accuracy of the measurements, the total carbon content was determined for all samples. A nearly constant value of $0.0018+/-0.0002$ moles of carbon was obtained in the case of the tests with oxidized Doyon tailings. Statistical calculations demonstrated that the total carbon content at any time could be considered equal to 0.0018 mol. This not only confirms the accuracy of the measurement but also indicates that changes 
in one form of carbon can be explained by changes in other forms. These tests were performed for every series of serum bottles and the results remained unchanged from the previous results. The total carbon was very stable for each series of essay.

\subsubsection{Evolution of leachate in contact with a mix of oxidized and unoxidized tailings}

As can be observed in Figure 1, the contact of organic leachate with a mix of oxidized and unoxidized tailings led to a rapid increase in $\mathrm{TOC}_{1}$ followed by a rapid decrease. The $\mathrm{TOC}_{1}$ eventually stabilized at a quite low value of $170 \mathrm{mg} / \mathrm{l}$. The initial increase was due to the phase balance induced by the solubilization of organic component during the first phase of the contact with the tailings and the leachate.

Around the $75^{\text {th }}$ day, a black precipitate was observed in all the samples filled with the mix and from there on, the odor of rotten eggs was detected when the serum bottles were opened. In addition, according to the results presented in Figure 7, the attenuation of organic carbon was accompanied by a significant production of solid inorganic carbon species. Moreover, the $\mathrm{pH}$ remained at 6.5 throughout the study (Figure 4a) and the redox potential leveled at $-150 \mathrm{mV}$ (Figure $4 \mathrm{~b}$ ) at the $75^{\text {th }}$ day.

As a consequence of the above-mentioned evidences, it can be stated that this attenuation is mediated by anaerobic microorganisms. Contrary to the control, given the absence of detection of methane in any serum bottles containing leachate and a mix of tailings, methanogenesis is not the cause of the attenuation. Moreover, the observations point in the direction of sulfate reduction as the main attenuation mechanism. Sulfatereducing microorganisms transform the organic matter present in the leachate into carbon dioxide and $\mathrm{H}_{2} \mathrm{~S}$ (reaction 9), which explains the rotten-egg odor. $\mathrm{H}_{2} \mathrm{~S}$ then reacted with iron 
to form a black precipitate of iron sulfide (FeS) (reaction 10) substantiated by the decrease of iron in the solution presented in Figure 4c.

Chemical reactions 9 and 10 present the sulfate-reduction reactions. Reaction 9 is mediated by sulfate-reducing microorganisms:

$$
\begin{aligned}
& 2 \mathrm{CH}_{2} \mathrm{O}+\mathrm{SO}_{4}^{2-}+\mathrm{H}^{+} \rightarrow 2 \mathrm{CO}_{2}+\mathrm{HS}^{-}+2 \mathrm{H}_{2} \mathrm{O} \quad ? \mathrm{G}^{0}=-59.9 \mathrm{~kJ} \\
& \mathrm{H}_{2} \mathrm{~S}+\mathrm{Fe}^{2+} \rightarrow \mathrm{FeS}+2 \mathrm{H}^{+}
\end{aligned}
$$

According to reaction 9, the decrease of $\mathrm{TOC}_{1}$ concentration would correspond to an increase in carbon dioxide. Figure 3 shows the production of carbon but the amount produced is less important than the decrease of $\mathrm{TOC}_{1}$. Moreover, Figure 7 showed that the decrease of $\mathrm{TOC}_{1}$ content is in relation with an increase of inorganic carbon concentration in the solid phase. This fact may be related with the decrease of soluble calcium (Figure 4d) from $4000 \mathrm{mg} / 1$ to non-detected values from initial time to 140 days. From this evidence, it seems that the carbon dioxide produced was converted in norganic carbon precipitated under the form of calcite. The evidence of the deposition of $\mathrm{CaCO}_{3}$ in relation with sulfate reduction reactions has already been demonstrated [19].

Sulfate reduction is often suggested as a good approach to improve water contaminated by acid mine drainage, because: 1) the production of hydrogen sulfide leads to metal precipitations (in the form of metallic sulfide) inside the tailings; 2) protons are consumed by the reaction, increasing the $\mathrm{pH} ; 3$ ) carbon dioxide can be dissociated in water and form 
carbonate, an important buffer; and 4) sulfate, often used as an indicator of the acidity of the water, is transformed into an insoluble form.

Sulfate-reduction seems to have only taken place spontaneously in the serum bottles containing a mixture of unoxidized and oxidized Doyon tailings. This means that the necessary conditions for sulfate-reduction are not present either in oxidized or unoxidized mine tailings alone during the study period. The hypotheses to explain this fact are that in oxidized tailings, the $\mathrm{pH}$ is too low to favor the development of sulfate-reducing microorganisms and in unoxidized tailings, it is possible that iron-reduction out-competes sulfate-reduction.

4.4 Evolution of leachate in contact with unoxidized tailings: influence of the Acid Generation Potential (AGP)

As shown in Figure 1, when deinking by-products leachate was placed in contact with unoxidized Grevet and Doyon tailings, the $\mathrm{TOC}_{1}$ rapidly attained its maximum values at 4800 and $4700 \mathrm{mg} / \mathrm{l}$ respectively. In the case of Laronde, however, the $\mathrm{TOC}_{1}$ concentration decreased from $2100 \mathrm{mg} / 1$ to $1200 \mathrm{mg} / \mathrm{l}$ during the first 14 days. As discussed previously, the peak in $\mathrm{TOC}_{1}$ concentration for unoxidized Grevet and Doyon tailings is accompanied by a decrease in $\mathrm{TOC}_{\mathrm{s}}$ concentrations. The $\mathrm{TOC}_{\mathrm{s}}$ concentration in Laronde serum bottles also decreased just after contact with deinking by-products leachate (Table 3). In the three cases, the decrease of $\mathrm{TOC}_{\mathrm{s}}$ concentration was not completely compensated by the $\mathrm{TOC}_{1}$ concentration. This means that there is a net decrease in total organic carbon when the deinking by-products leachate is placed in contact with unoxidized mine tailings. Indeed, 
Table 3 shows that the total organic carbon decreases by as much as 0.007 mol for Grevet, $0.002 \mathrm{~mol}$ for Doyon and $0.0106 \mathrm{~mol}$ for Laronde during the first 14 days. Despite differences in the behavior of $\mathrm{TOC}_{1}$ in the beginning of the tests, these values represent quite similar net TOC decreases (21.5\% for Grevet, 23.7\% for Doyon and 27.4\% for Laronde).

According to Figure 3, carbon dioxide was also produced in the first days and attained a constant concentration of $27 \%$ (Grevet), $18 \%$ (Laronde) and 1\% (Doyon). It is likely that the $\mathrm{CO}_{2}$ production is the consequence of acid-base balance that followed mixing of unoxidized mine tailings with deinking by-products leachate. The stabilization of $\mathrm{CO}_{2}$ concentrations after the initial phase excludes the possibility of aerobic degradation associated with an eventual oxygen intrusion.

As shown in Figure 1, after an initial phase during which important fluctuations in $\mathrm{TOC}_{1}$ concentrations were observed, the $\mathrm{TOC}_{1}$ concentrations for the Doyon, Grevet and Laronde tailings stabilized at approximately $2300 \mathrm{mg} / 1,2450 \mathrm{mg} / \mathrm{l}$ and $2600 \mathrm{mg} / \mathrm{l}$, respectively. Towards the end of the study, the concentrations of $\mathrm{TOC}_{1}$ in all three tailings eventually converged to $2600 \mathrm{mg} / \mathrm{l}$. Statistical calculations were performed to evaluate to what degree the three $\mathrm{TOC}_{1}$ evolutions may be considered similar after 50 days. The statistical results obtained (not presented here) allow to confirm the hypothesis that the three curves are superimposed. These results indicate that the AGP of the tailings did not affect the long-term evolution of TOC in the liquid phase

As shown in Table 4, the total organic carbon concentrations in the solid phase $\left(\mathrm{TOC}_{\mathrm{s}}\right)$ decreased by as much as $75 \%$ in all three unoxidized tailings. The organic content of tailings is often considered as insignificant; consequently their impact is seldom discussed in technical literature. 
Since the serum bottles constitute a closed system, the continuous decrease in organic carbon in the solid phase (Table 4) had to be compensated by either an increase in organic carbon in the liquid phase - which did not occur after 75 days (Figure 1) - or an increase in inorganic carbon. The latter is illustrated in Figure 5 for the case of the unoxidized Doyon tailings and was also observed for the other two tailings (results not presented). However, it is unlikely that the organic carbon in the solid phase $\left(\mathrm{TOC}_{\mathrm{s}}\right)$ can be converted directly into inorganic carbon in the solid phase $\left(\mathrm{IC}_{\mathrm{s}}\right)$. A possible path that is presently being investigated would suggest that this transformation takes place in the liquid phase. That is:

$$
\stackrel{l}{T_{O C C}} \stackrel{2}{\rightarrow} \mathrm{TOC}_{l} \stackrel{2}{\rightarrow} \mathrm{IC} C_{l} \stackrel{3}{\rightarrow} I C_{S}
$$

The first step would correspond to physical dissolution (or/and fermentation, if the system allows development of fermentative microorganisms), whereas microorganisms would mediate the second phase. The third phase would be associated with precipitation of carbonates.

The biochemical environments prevailing in the serum bottles depend on the unoxidized tailings. Indeed, as shown in Figure 8a and Figure 8b, the evolutions in $\mathrm{pH}$ and in redox potential indicate that two different biochemical environments developed: one where a lightly oxidizing environment is taking place (Laronde), and another where a reducing environment prevails (Doyon and Grevet).

Methane was never detected in the serum bottles containing unoxidized tailings. As a consequence, methanogenesis is excluded as a possible mechanism of $\mathrm{TOC}_{\mathrm{s}}$ degradation. This is probably due to inhibition of methanogenic microorganisms measured in the control 
following contact with the tailings. Indeed, at sulfate concentrations higher than $18 \mathrm{mg} / \mathrm{l}$, methanogenic microorganisms start to become inhibited and total inhibition occurs at sulfate concentrations between 910 and $2400 \mathrm{mg} / 1$ [20]. As shown in Table 1, the sulfateconcentration for Grevet, Doyon and Laronde are $4340 \mathrm{mg} / \mathrm{l}, 3504 \mathrm{mg} / \mathrm{l}$ and $2260 \mathrm{mg} / \mathrm{l}$, respectively. Sulfate-reduction is also excluded due to the absence of the characteristic rotten-egg odor and of black precipitate in the serum bottles containing unoxidized tailings mixed with leachate.

The hypothesis of iron-reduction biodegradation is advanced. Indeed, the study of ironreducing microorganisms in tailings is usually not investigated in the context of organic biodegradation in an AMD environment; however iron-reduction is thermodynamically more favorable than sulfate-reduction or methanogenesis when Fe(III) is available [21]. The latter is the case in unoxidized tailings. Moreover, the $\mathrm{pH}$ and the ORP measured for the Grevet and Doyon unoxidized tailings (Figure 8a and Figure 8b) correspond to the ones measured in an environment affected by iron-reduction.

Iron was measured in the liquid phase as total iron. As shown in Figure $8 \mathrm{c}$, the concentrations of total iron for Grevet and Doyon first increased from $20 \mathrm{mg} / \mathrm{l}$ to $200 \mathrm{mg} / \mathrm{l}$ and then decreased to stabilize at a level similar to the initial value. For Laronde, however, the iron concentration is maintained at a level superior to $300 \mathrm{mg} / 1$ throughout the study. Reddish bubbles appeared in Laronde serum bottles, an indication that soluble iron oxides were formed. The fact that soluble iron was formed (Figure 8c) seems to indicate that the degradation of organic matter is mainly due to iron-reduction, as expressed by the simplified reaction 11: 
$\mathrm{CH}_{2} \mathrm{O}+4 \mathrm{Fe}(\mathrm{OH})_{3}+8 \mathrm{H}^{+} \rightarrow \mathrm{CO}_{2}+4 \mathrm{Fe}^{2+}+11 \mathrm{H}_{2} \mathrm{O}$

In the case of Laronde tailings, $\mathrm{Fe}^{2+}$ reacts with water to form iron oxide according to the simplified reaction 12 .

$\mathrm{Fe}^{2+}+4 \mathrm{H}_{2} \mathrm{O} \rightarrow \mathrm{Fe}(\mathrm{OH})_{2}+4 \mathrm{H}^{+}$

The carbonic acid is also dissociated in water according to reaction 13 , which is $\mathrm{pH}$ dependent.

$\mathrm{H}_{2} \mathrm{CO}_{3} \rightarrow \mathrm{CO}_{3}^{2-}+2 \mathrm{H}^{+}$

According to reactions 14 and 15 , once dissociated, the $\mathrm{CO}_{3}{ }^{2-}$ reacts with soluble iron and soluble calcium to form precipitates, which explains the low iron and calcium concentration values found in Grevet and Doyon serum bottles.

$$
\begin{aligned}
& \mathrm{CO}_{3}{ }^{2+}+\mathrm{Ca}^{2+} \rightarrow \mathrm{CaCO}_{3} \\
& \mathrm{CO}_{3}{ }^{2+}+\mathrm{Fe}^{2+} \rightarrow \mathrm{FeCO}_{3}
\end{aligned}
$$

According to Lovley [22], sulfate-reducing microorganisms, such as Desulfovibrio $s p$. in presence of $\mathrm{Fe}(\mathrm{III})$ can reduce iron and precipitate calcite. Iron-reduction, being thermodynamically favored in comparison with sulfate-reduction that could explain the absence of sulfate-reduction in the serum bottle filled with unoxidized mine tailings. 
Moreover, contrary to the mixture of unoxidized and oxidized mine tailings, the $\mathrm{TOC}_{1}$ concentration is stabilized at $2600 \mathrm{mg} / \mathrm{l}$, quite a high value. It seems that the microorganisms degrading the organic matter are inhibited in the environment of only unoxidized mine tailings.

\section{CONCLUSIONS}

In order to observe the interactions when an organic leachate is in contact with acid producing mine tailings, a total of 180 anaerobic serum bottles were filled with organic leachate and different mixes of mine tailings plus a control containing only the organic leachate. Over a period of 230 days, a number of serum bottles were periodically opened to perform different analyses in order to follow the evolution of the liquid phase over time.

In the serum bottles containing only leachate, the organic content initially at $1300 \mathrm{mg} / 1$ increases at first and then continually decreases down to $600 \mathrm{mg} / 1$ after 230 days. When in contact with unoxidized tailings, the organic carbon in the liquid phase, after a period of time necessary for stabilization, remains constant at $2600 \mathrm{mg} / \mathrm{l}$, independently of the acid generation potential. When in contact with oxidized tailings, the organic carbon in the liquid phase remains fairly constant throughout the observation period at $2300 \mathrm{mg} / \mathrm{l}$. When in contact with a mix of oxidized and unoxidized tailings, the organic content in the liquid phase dropped rapidly to about $170 \mathrm{mg} / \mathrm{l}$ after 100 days.

The mechanisms controlling the evolution of organic carbon in the liquid phase were very different depending on the conditions. Without contact with tailings (control), methane production was observed and methanogenesis seems to be the cause of the biodegradation 
of the organic leachate. This mechanism of attenuation was, however, totally absent in all the serum bottles containing leachate in contact with mine tailings. This was certainly due to the inhibition by sulfate of methane-producing microorganisms.

When in contact with tailings, the attenuation reactions depend on the oxidation state of the tailings. In serum bottles filled with oxidized mine tailings, no degradation of the organic component of the leachate was observed throughout the 230 days of observation, most possibly due to the acidic environment. When in contact with unoxidized mine tailings, the organic components seem to be oxidized by iron-reduction. However, the physico-chemical characteristics of the resulting pore water depend on the AGP of the mine tailings. In the serum bottles with a mix of unoxidized and oxidized tailings, the decrease of organic carbon is related to the development of sulfate-reducing microorganisms. The sulfate-reduction took place only in the mix tailings. It seems that in the unoxidized tailings, the iron-reduction, thermodynamically favorable, out-competes the sulfate-reduction and in the oxidized tailings, the initial conditions are inhibitors of the development of sulfatereduction.

\section{ACKNOWLEDGEMENTS}

This study was supported by a NSERC grant (CRD 192179) in partnership with Industries Cascades Inc., Les Papiers Perkins Ltd. and Désencrage Cascades Inc. Mrs. Panarotto was sponsored by $\mathrm{CNPq}$ - Brazil. The help of Prof. Bruno Bussière, from UQAT, in obtaining the tailings is also acknowledged. 


\section{REFERENCES}

[1] H.L. Ehrlich in: D.J. Kushner (Ed.), Microbial Life in Extreme Environments, Academic Press, London, 1978, p. 389.

[2] M. Ledin and K. Pedersen, Earth Sc. Rev. 41 (1996) 67.

[3] M. Tassé, D. Germain, C. Dufour and R. Tremblay in: Proceed. of the symp. on acid rock drainage'97, Vancouver, Canada, 1997, p. 1627.

[4] W.G. Pierce, N. Belzide, M.E. Wiseman and K. Winterhalder in: The int. land recl. and mine drainage conf. and 3rd int. conf. on the abatement of acidic drainage, Pittsburgh, 1994, p. 148.

[5] G. Bechard, H. Yamazaki, W.D. Gould and P. Bechard, J. environ. quality 23 (1994) 111.

[6] A.R. Cabral, G. Lefebvre, F. Burnotte, C.T. Panarotto and E. Pastore in: $2^{\circ}$ Seminario de meio ambiante em industrias de processo, Sao Paolo, Bresil, 1999, p. 56.

[7] A. Cabral, I. Racine, F. Burnotte and G. Lefebvre, Canadian Geotechnical Journal 37 (2000) 201.

[8] C.E. Teixeira in: Département de génie civil, Université de Sherbrooke, Sherbrooke (Qc) Canada, 2001, p. 195.

[9] C.T. Panarotto, A.R. Cabral, F. Burnotte, E. Pastore and G. Lefebvre in: Congrés APGCQ, Rouyn-Noranda, 1999.

[10] N. Wakao, T. Takahashi, Y. Sakurai and H. Shiota, J. Ferment. Technol. 57 (1979) 445.

[11] I.E. Chang, P.K. Shin and B.H. Kim, Water Res. 34 (2000) 1269.

[12] B. Christensen, M. Laake and L. Torleiv, Water Res. 30 (1996) 1617.

[13] J.R. Pichtel and W.A. Dick, Soil Biology and Biochemistry 23 (1991) 109.

[14] K. Ueki, A. Ueki, K.I. Itoh, T. Tanaka and A. Satoh, J. Environ. Sci. Health A26 (1991) 1471.

[15] A. Peppas, K. Komnitsas and I. Halikia, Miner. Eng. 13 (2000) 563.

[16] S.R. Burckhard, A.P. Schwarb and M.K. Banks, J. Hazard. Mater. 41 (1995) 135.

[17] S.D. Machener and T.R. Wildeman, J. Contamin. Hydrol. 9 (1992) 115.

[18] A.R. Cabral, G. Lefebvre, M.F. Proulx, C. Audet, M. Labbé and C. Michaud in: Proceed. of the symp. on acid rock drainage'97, Vancouver, Canada, 1997, p. 1109.

[19] H.L. Ehrlich in: M. Dekker (Ed.), Geomicrobiology 2nd Edition Revised and Expanded, 1990, p. 157.

[20] E. Choi and J.M. Rim, Water Sci. Technol. 23 (1991) 1259.

[21] D.R. Lovley and E.J.P. Phillips, Appl. Environ. Microbiol. 51 (1986) 683.

[22] D.R. Lovley, Adv. Agron 54 (1995) 175. 
Table 1 - Characteristics of tailings

\begin{tabular}{|c|c|c|c|c|}
\hline & Grevet & Doyon & Doyon ox & Laronde \\
\hline $\mathrm{pH}$ & 5.39 & 8.93 & 3.18 & 5.15 \\
\hline Organic Matter $(\%)$ & 8,39 & 2,07 & 0,00 & 11.51 \\
\hline Burnt matter $(\%)$ & 13.99 & 2.75 & 0.65 & 18.67 \\
\hline Sulfur (\%) & 21.7 & 3.94 & & 30.59 \\
\hline Soluble sulfate $\left(\mathrm{mg} \cdot \mathrm{g}^{-1}\right)$ & 2.17 & 1.75 & 2.65 & 1.13 \\
\hline Soluble iron (mg. $\left.\mathrm{kg}^{-1}\right)$ & 2.58 & 2.84 & 26.24 & 2.77 \\
\hline $\mathrm{AP}\left(\mathrm{kg} \mathrm{CaCO} \cdot \mathrm{t}^{-1}\right)$ & -678 & -123 & & -956 \\
\hline $\mathrm{NP}\left(\mathrm{kg} \mathrm{CaCO} \cdot \mathrm{t}^{-1}\right)$ & 60 & 41 & & 20 \\
\hline $\operatorname{AGP}\left(\mathrm{kg} \mathrm{CaCO} \cdot \mathrm{t}^{-1}\right)$ & -618 & -82 & & -936 \\
\hline
\end{tabular}

$\mathrm{AP}=$ Acidification Potential

$\mathrm{NP}=$ Neutralization Potential

AGP $=$ Acid Generation Potential 
Table 2 - Characteristics of the leachate

\begin{tabular}{lc}
\hline & Leachate \\
\hline $\mathrm{pH}$ & 6.8 \\
Redox potential $(\mathrm{mV})$ & -13.8 \\
Conductivity ( $\mu \mathrm{mH} / \mathrm{s})$ & 4325 \\
$\mathrm{COD}(\mathrm{mg} / \mathrm{l})$ & 9435 \\
TOC $(\mathrm{mg} / \mathrm{l})$ & 1548 \\
Iron $(\mathrm{mg} / \mathrm{l})$ & 14.9 \\
Calcium $(\mathrm{mg} / \mathrm{l})$ & 1749.01 \\
\hline
\end{tabular}


Table 3 - Variations of TOC in liquid phase and TOC in solid phase from 0 to 14 days in serum bottles (negative number means a loss and positive number means a gain)

\begin{tabular}{lcccccc}
\hline $\begin{array}{c}\text { From 0 to 14 day period } \\
(\mathrm{mol})\end{array}$ & Control & Grevet & Doyon & $\begin{array}{c}\text { Doyon } \\
\text { ox }\end{array}$ & $\begin{array}{c}\text { Doyon } \\
\text { mix }\end{array}$ & Laronde \\
\hline Variations of $\mathrm{TOC}_{1}(\mathrm{~mol})$ & $\begin{array}{c}0.0005 \\
\text { No solid } \\
\text { phase }\end{array}$ & -0.002 & 0.002 & 0.0004 & 0.002 & -0.0006 \\
Variations of $\mathrm{TOC}_{\mathrm{s}}(\mathrm{mol})$ & -0.004 & 0 & -0.004 & -0.01 \\
$\begin{array}{l}\text { Difference }\left(\mathrm{TOC}_{\mathrm{s}}+\mathrm{TOC}_{\mathrm{l}}\right) \\
(\mathrm{mol})\end{array}$ & $\begin{array}{c}0.0005 \\
\mathrm{CO}_{2} \text { and } \mathrm{CH}_{4}(\mathrm{~mol})\end{array}$ & -0.007 & -0.002 & 0.0004 & -0.002 & -0.0106 \\
\hline
\end{tabular}

Table 4 - Evolution of TOC in the solid phase (mg)

\begin{tabular}{lccc}
\hline TOC $_{\mathrm{s}}(\mathrm{mg})$ & Grevet & Doyon & Laronde \\
\hline 0 & 424,30 & 104,51 & 582,19 \\
14 days & 321,27 & 72,95 & 424,06 \\
42 days & 290,25 & 69,58 & 201,90 \\
75 days & 189,21 & 49,09 & 182,73 \\
106 days & 393,59 & 71,66 & 160,05 \\
135 days & 149,45 & 35,50 & 194,64 \\
163 days & 88,92 & 26,93 & 197,80 \\
199 days & 120,53 & 33,60 & 243,71 \\
231 days & 107,01 & 24,41 & 147,37 \\
& & & \\
\% of TOC & & & \\
attenuation & 74,78 & 76,65 & 74.69 \\
\hline
\end{tabular}




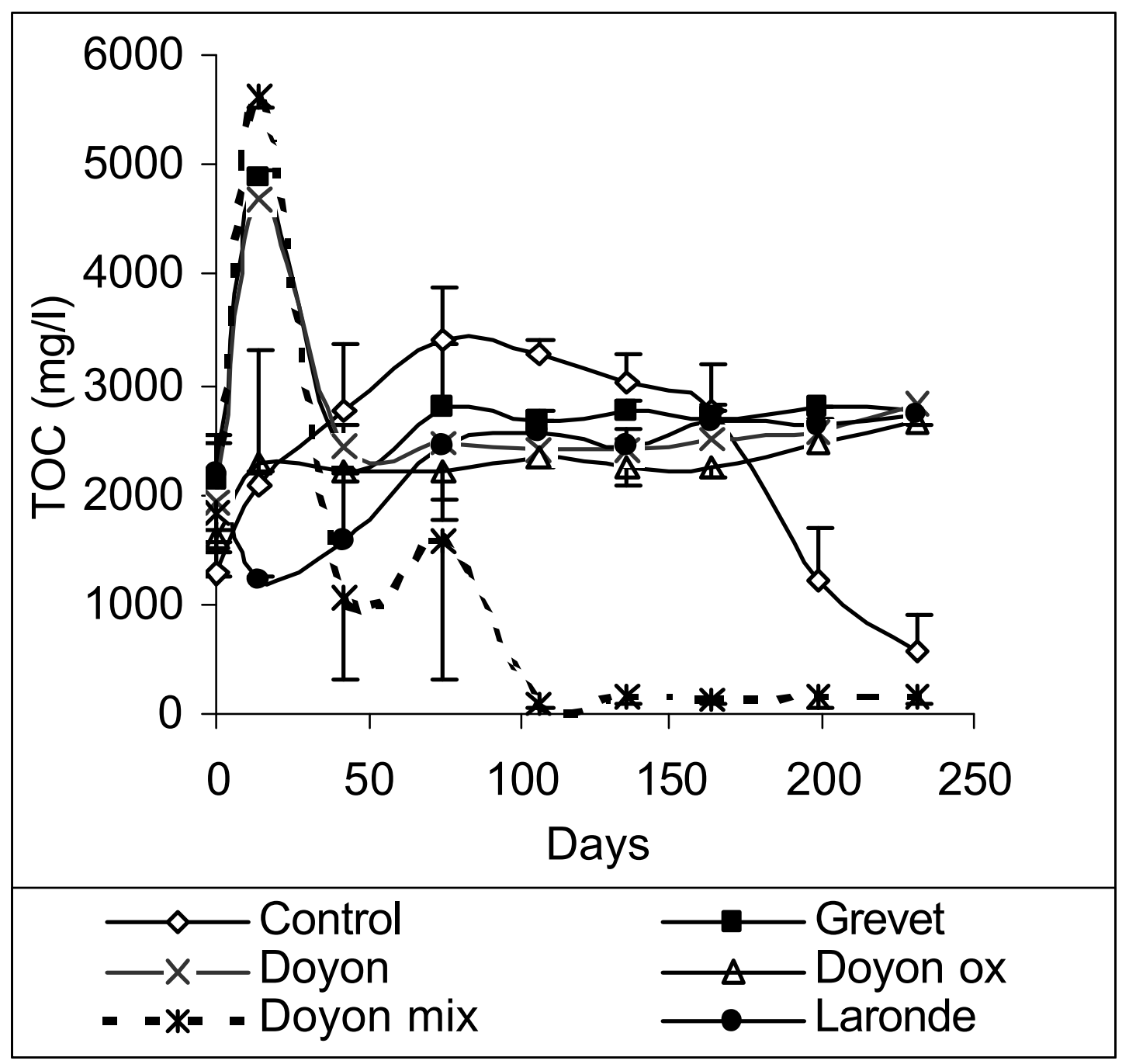

Note: each point represents the mean of 3 analyses

Figure 1 - Evolution of TOC in leachate only (control) and in the liquid phase of the leachate/tailings mixes 


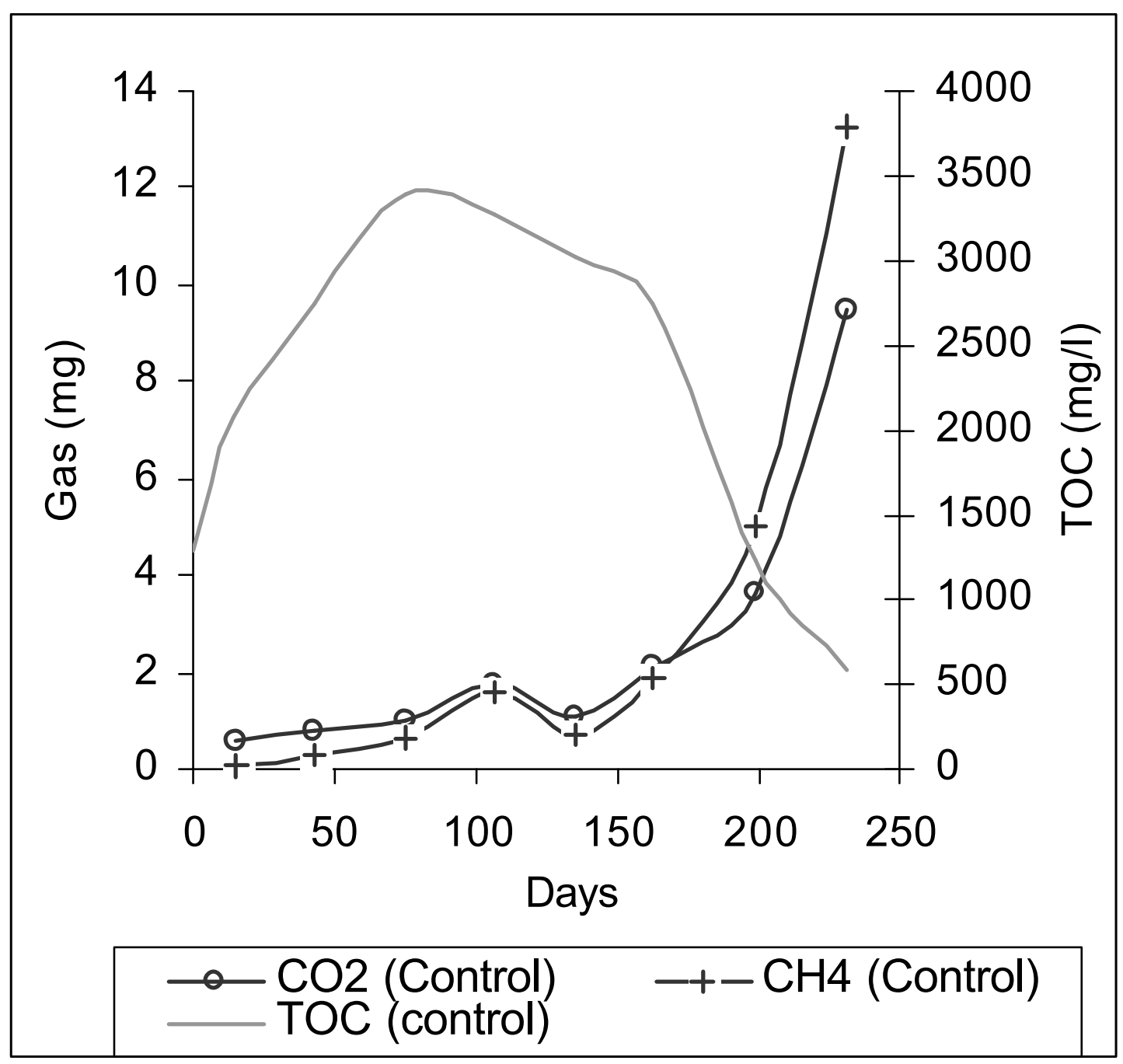

Note: each point represents the mean of 3 analyses

Figure 2 - Dioxide of carbon and methane produced by control samples 


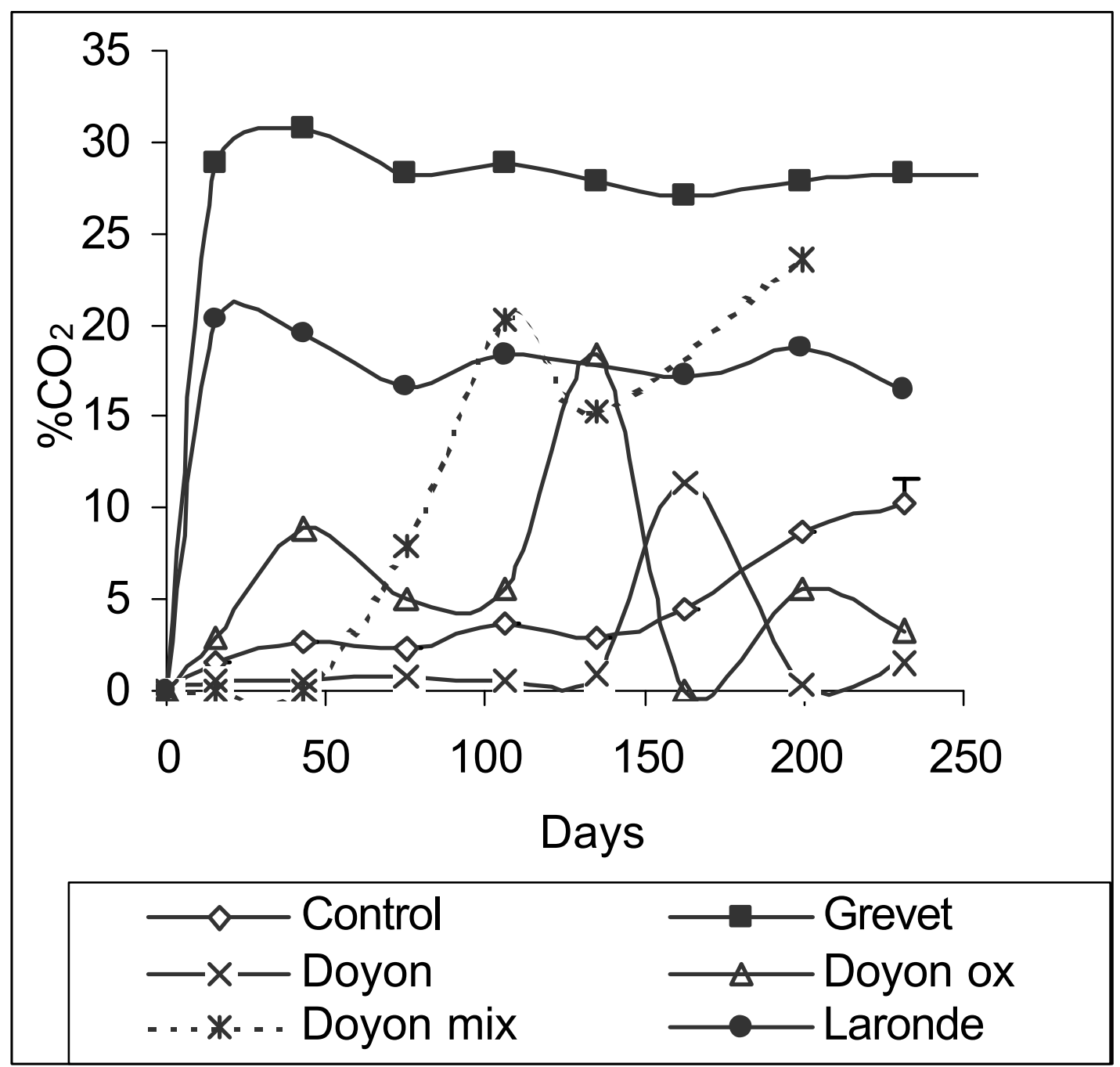

Note: each point represents the mean of 3 analyses

Figure 3 - Carbon dioxide evolution in gaseous phase 

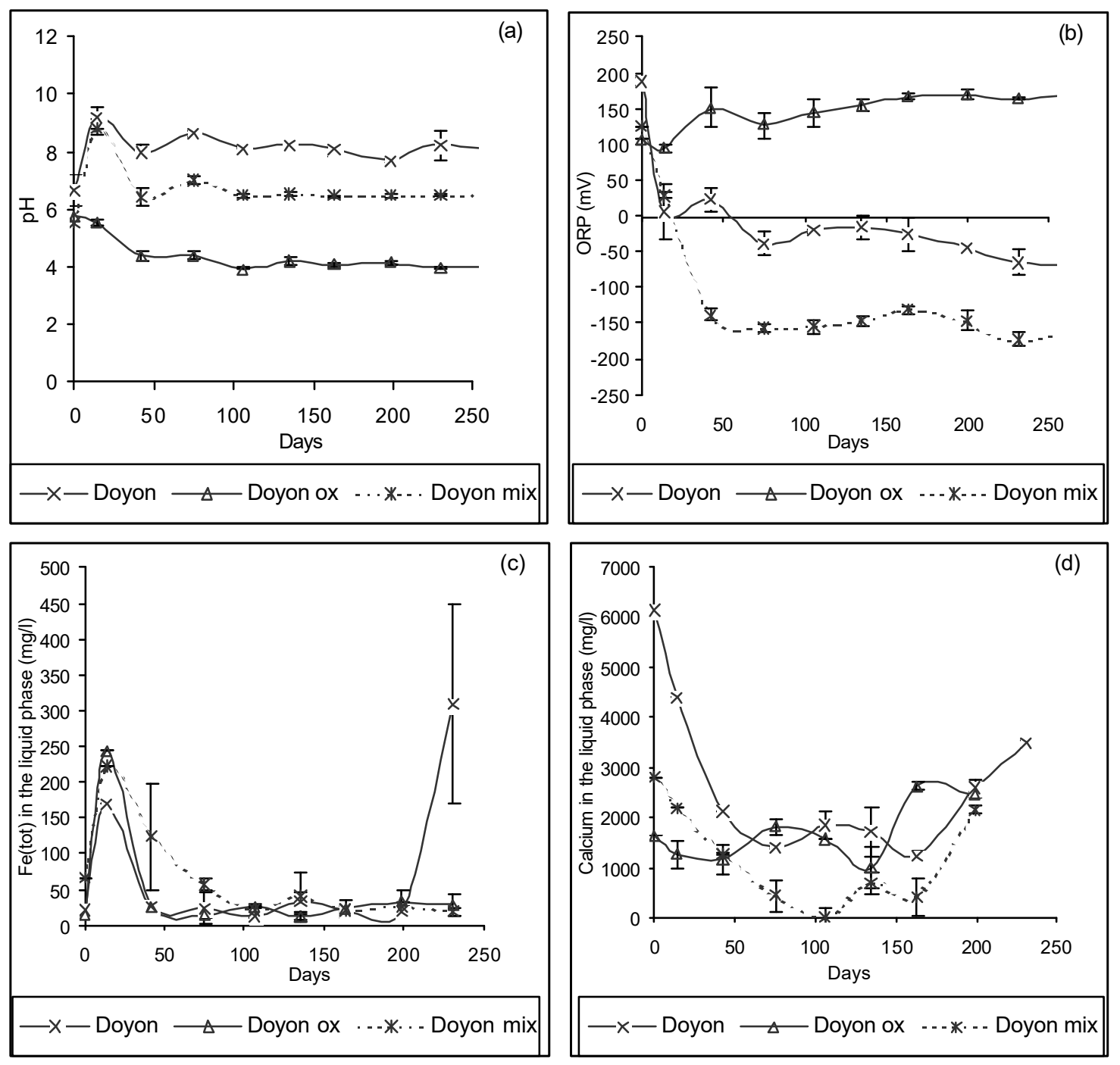

Note: each point represents the mean of 3 analyses

Figure 4 - Evolution of: (a) $\mathrm{pH}$; (b) redox potential; (c) total iron; and (d) calcium in the liquid phase of the serum bottle filled with unoxidized (Doyon), oxidized (Doyon ox) and mix (Doyon mix) mine tailings 


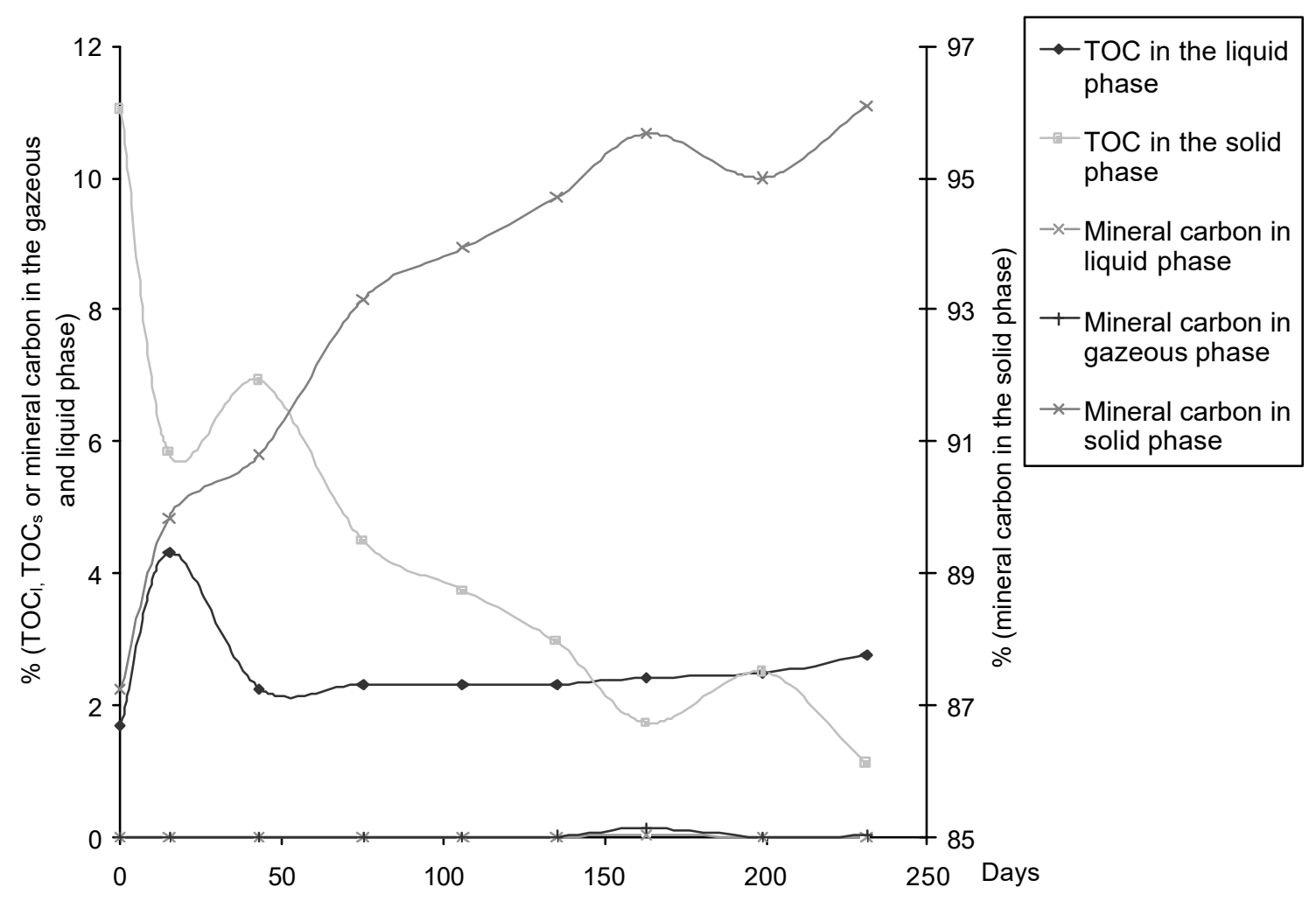

Note: each point represents the mean of 3 analyses

Figure 5 - Evolution of the frequency of the different carbon species in serum bottles filled with unoxidized Doyon tailings 


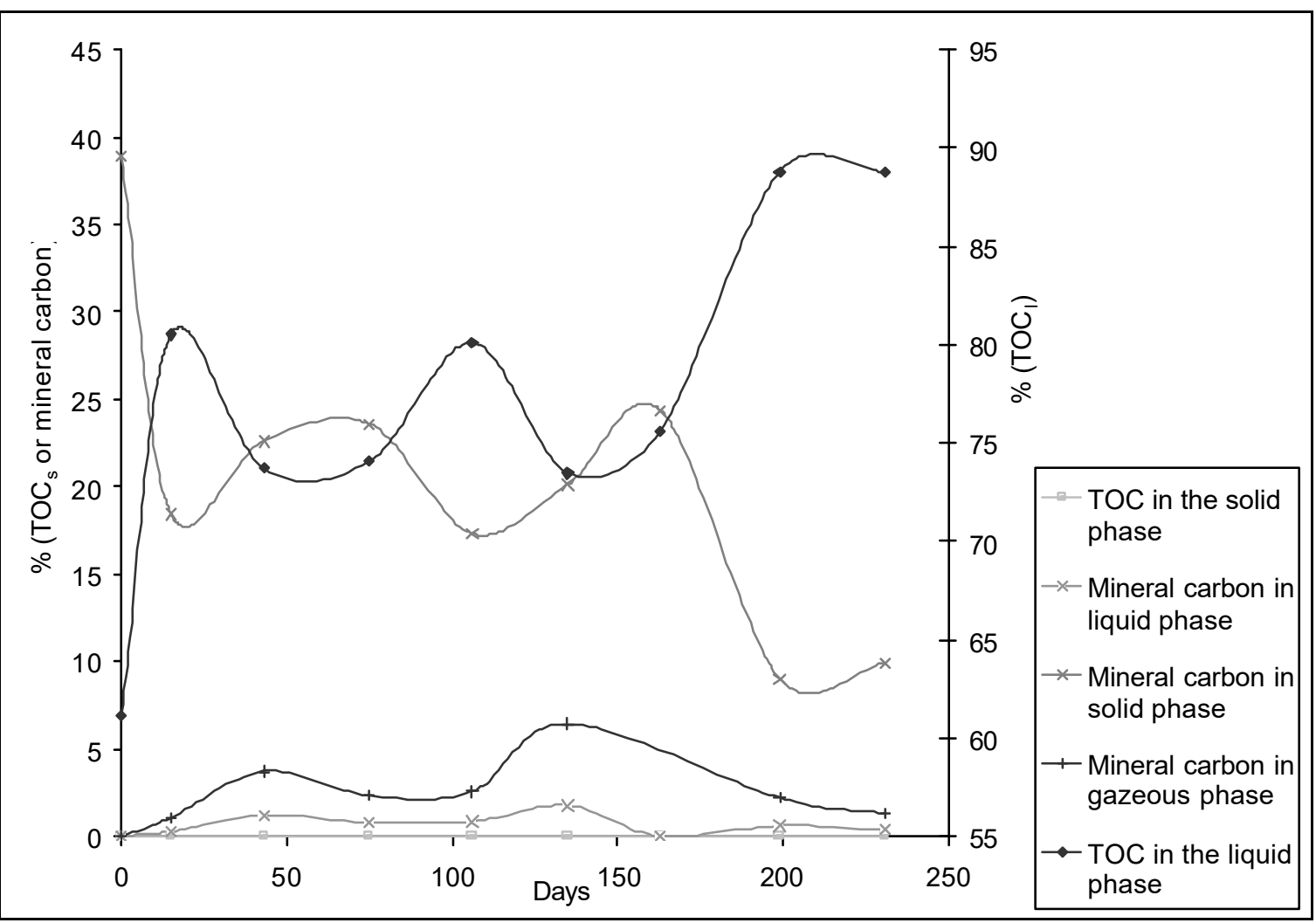

Note: each point represents the mean of 3 analyses

Figure 6 - Evolution of the frequency of the different carbon species in serum bottles filled with oxidized Doyon tailings 


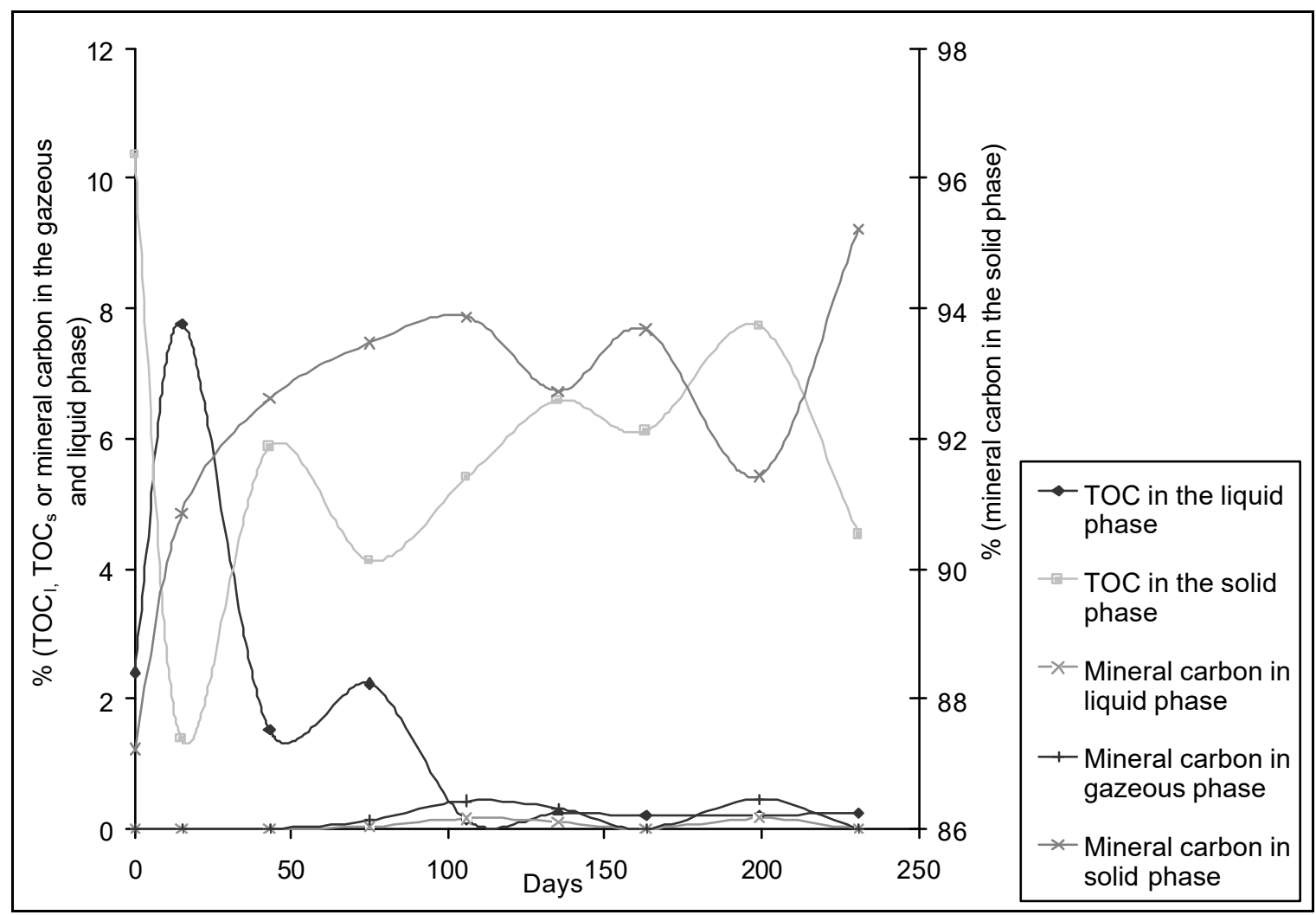

Note: each point represents the mean of 3 analyses

Figure 7 - Evolution of the frequency of the different carbon species in serum bottles filled with a mix of unoxidized and oxidized tailings 

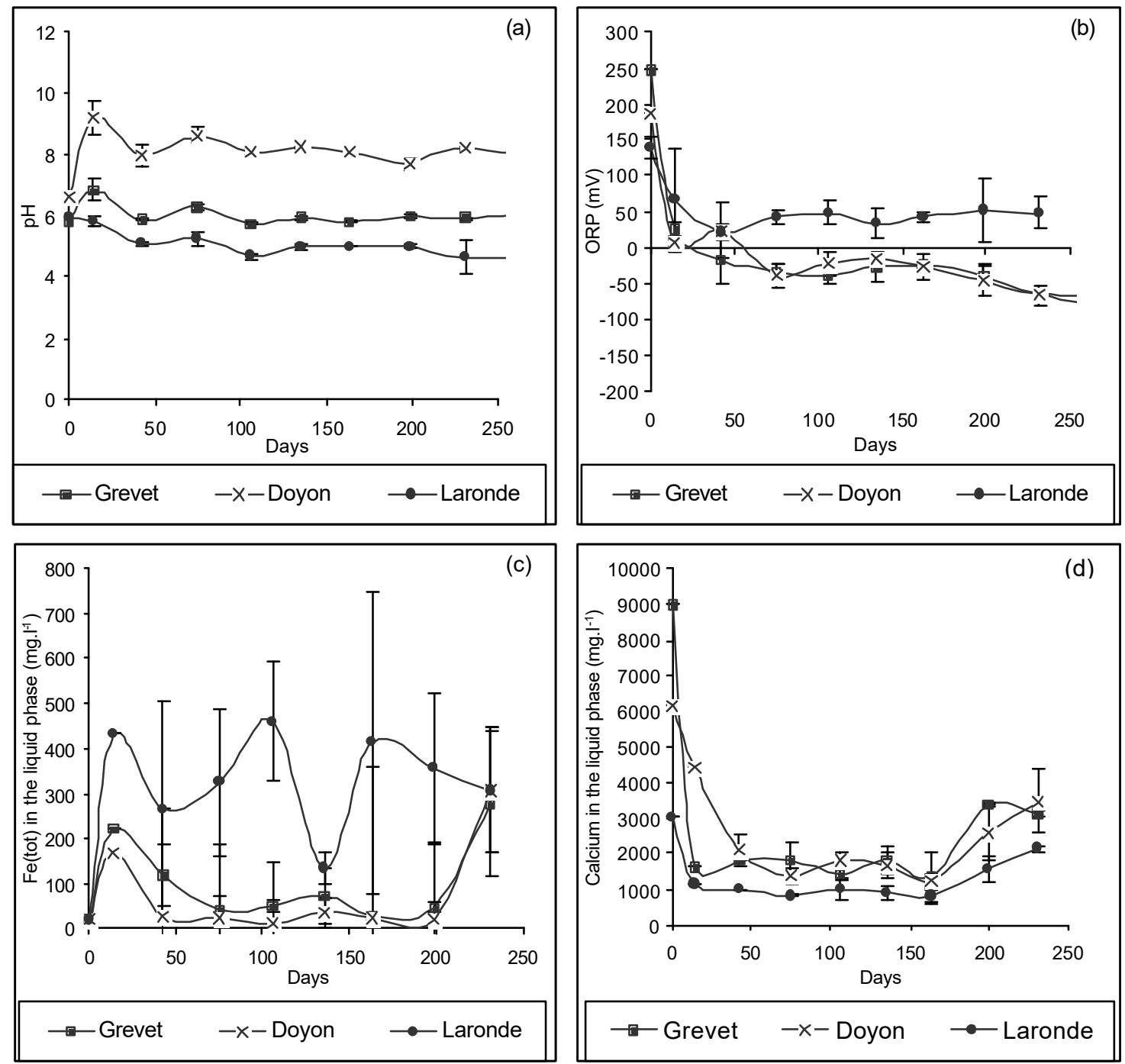

Note: each point represents the mean of 3 analyses

Figure $8-\mathrm{pH}(\mathrm{a})$, oxidoreduction potential (b), total soluble iron (c) and calcium (d) evolution in serum bottle containing unoxidized mine tailings 